\title{
JUURNAL.RU
}

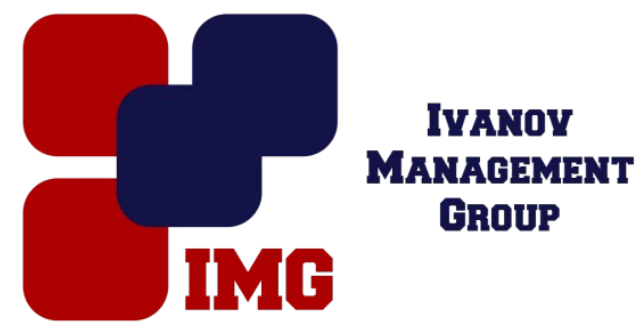

Шевченко В.В. Историко-этнографический и архитектурный музей-заповедник «Старая Сарепта» Волгоград, Россия

doi: 10.18411/lj-25-12-2016-2-04

idsp 000001:lj-25-12-2016-2-04

\section{Депортация немцев Красноармейска в 1941 г.}

\section{Аннотация}

Статья посвящена одному из самых трагических эпизодов истории немцев Поволжья - депортации 1941 г. Депортация затронула также и жителей южного района Сталинграда - поселка Красноармейск - бывшей немецкой колонии Сарепта. Не отрицая жестокости и несправедливости этой меры, автор в то же время отмечает объективно вынужденный ее характер в условиях катастрофического для СССР начала Великой Отечественной войны и возможных подрывных действий «пятой колонны».

Ключевые слова: Великая Отечественная война, депортация, немцы Поволжья, Сталинград, Красноармейск.

Начало Великой Отечественной войны стало трагическим событием для граждан СССР всех национальностей, в том числе и для поволжских немцев. Предпосылки негативного отношения советского руководства к российским немцам появились в 1930-х гг. и были во многом обусловлены сложной международной обстановкой: было очевидно, что блок Германии, Италии и Японии приложит все усилия для установления нового мирового порядка и передела сфер влияния. Англия и Америка при этом не только весьма ощутимо инвестировали в развитие военной промышленности нацистского рейха, но фактически нивелировали все усилия Советского Союза к созданию в Европе системы коллективной безопасности для остановки нарастания угрозы фашистской агрессии. Не последнюю роль играло при этом и то, что немцы Поволжья не вполне лояльно относились к существующему строю [5, с. 6]. Во многом негативное отношение к навязываемым ценностям сталинского социализма было предопределено сложившимся ценностным укладом немецких колоний. При этом на первом месте стояли не борьба за сохранение и развитие своей государственности, а за сохранение традиционных устоев, основанных на таких ценностях, как собственность, церковь, школа [11].

Приход к власти в Германии нацистов и гражданская война в Испании, наглядно показавшая, что такое «пятая колонна», и к каким последствиям приводит ее деятельность, еще больше обострили негативное отношение со 
стороны властей к российским немцам.

Впрочем, нельзя отрицать и того, что немецкая разведка действительно активно действовала на территории Советского Союза. Масштабы вовлеченности в данную деятельность российских немцев являются весьма дискуссионным вопросом, однако отрицать отдельные случаи подобного коллаборационизма, безусловно, не стоит.

В 1937 г. ситуация накаляется. Специальное сообщение наркома внутренних дел Ежова за № 55820 гласит: «Сов. секретно. Секретарю ЦК ВКП(б) тов. Сталину: Управлением НКВД по Западно-Сибирскому краю за последний год вскрыт ряд диверсионных шпионских и террористических организаций, созданных японской, германской и польской разведками на предприятиях Кузбасса, Томской железной дороге и прилегающих районах... Иностранные разведки, преимущественно германская, используют для шпионажа и диверсии представителей германских фирм и специалистов иноподданных, работающих на предприятиях и в учреждениях Западно-Сибирского края, где осели иностранноподданные в количестве 727 человек, из них: германских подданных 179 человек, австрийских - 73, польских - 30, чехословацких - 256 и других государств - 189».

В частности Ежов указывал, что в раскрытую на Анжерском руднике шпионско-диверсионную группу «были вовлечены как иностранные специалисты, так и немцы - советские граждане Якимех и Флорен, - связанные с германским консульством в Новосибирске» [14, с. 92 - 94].

При данных обстоятельствах склонность к перестраховкам Сталина заставила пойти его на крайний шаг. На записке к протоколу заседания Политбюро ЦК ВКП(б) от 20 июля 1937 г., на котором обсуждался данный вопрос, Сталин указал: «Всех немцев на наших военных, полувоенных и химических заводах, на электростанциях и строительствах, во всех областях всех арестовать».

25 июля 1937 г. вышел Оперативный приказ НКВД СССР № 00439 «Об операции по репрессированию германских подданных, подозревавшихся в шпионаже против СССР» (в первую очередь имелись в виду работавшие на оборонных заводах и на транспорте иностранные специалисты, которых само же советское государство пригласило ранее, за дефицитом собственных).

Аресты начались в ночь на 30 июля. Через неделю, 6 августа, в СССР было арестовано 340 человек германских подданных, из них 12 в Сталинградской области [17, с. 39].

C осени «немецкая операция» постепенно стала распространяться на некоторые категории советских немцев и других граждан, обвиняемых в связях с Германией и шпионаже в ее пользу в соответствии все с тем же приказом, предписывавшим «вновь выявляемых в процессе следствия германских агентовшпионов, диверсантов и террористов, как из числа советских граждан, так и подданных других государств, немедленно арестовывать независимо от места их работы».

Всего до середины ноября 1938 г. в Сталинградской области в рамках «немецкой операции» был осужден 1271 человек, причем большинство (1019 человек) были приговорены к высшей мере наказания [17, с. 78].

C началом Второй мировой войны международная обстановка резко обострилась. Исследователь немецкой «пятой колонны» времен войны Л. де Ионг 
писал: «Знак свастики всюду был притягательным для лиц немецкого происхождения... Третий рейх, словно магнит, притягивал к себе немцев, разбросанных по всему миру» [12, с. 47].

Страх перед «пятой колонной» в ряде стран превращался в антинемецкую истерию. Руководство многих стран принимало огульные репрессивные меры в отношении населения, этнически родственного противнику. Практика депортации и интернирования применялась по отношению к немцам практически во всех странах, подвергшихся агрессии Германии [12, с. 49].

Несмотря на определенные разногласия с властями, весть о нападении Гитлера на Советский Союз была для большинства поволжских немцев таким же потрясением, как и для других граждан страны.

В первые же дни войны более 2500 жителей Автономной Советской Социалистической Республики Немцев Поволжья подали в военкоматы заявления с просьбой об отправке их добровольцами на фронт. Так, в Саратовской области доля поволжских немцев среди добровольцев, подавших указанные заявления, составляла $40 \%$.

Вместе с тем, практически все получали отказ, мотивированный потребностями армии в определенных специалистах. Данное обстоятельство, как следует из докладной записки первого секретаря Саратовского обкома ВКП(б) С. Маслова, вызывало недовольство со стороны немецкого населения [3, с. 41$].$

Ряд исследователей акцентирует внимание на отсутствии каких-либо системных фактов сотрудничества между Третьим рейхом и немцами, проживавшими на Днепре, у Черного моря, на Дону или в Поволжье [12, с. 102 $108 ; 4$, с. 12 - $14 ; 2$, с. 172$]$.

Примечательно, что, например А.А. Герман, фактически признает, что одним из факторов, не позволившим сложиться такому сотрудничеству, стало «наличие мощного и разветвленного полицейско-карательного аппарата, непрерывно выискивавшего и жестоко каравшего «врагов народа» [5, с. 15].

Таким образом, можно сделать вывод, что так называемая «Немецкая операция» НКВД 1938 г., несмотря на всю жестокость, в определенной степени все-таки достигла поставленных целей. Вместе с тем, о полном искоренении «пятой колонны» среди российских немцев, по-видимому, речь все-таки не шла.

3 августа 1941 г. командование Южным фронтом направило Верховному Главнокомандующему И.В. Сталину и Главкому Южного направления С.М. Буденному донесение № 28, в котором говорилось: «...Военные действия на Днестре показали, что немецкое население стреляло из окон и огородов по отходящим нашим войскам. Установлено также, что вступающие немецкофашистские войска в немецкой деревне 1.8 .41 г. встречались хлебом, солью...» [16, 447 - 448].

Отметим, что истинные масштабы коллаборационизма со стороны российских немцев являются отдельным, дискуссионным и мало разработанным вопросом. Например, В.Л. Мартыненко ставит под сомнение факты, изложенные в вышеупомянутом донесении, полагая, что оно появилось «не без прямой инициативы со стороны НКВД для формального обоснования целесообразности дальнейших репрессивных действий и массовых депортаций в отношении представителей немецкой национальности» [15, с. 127].

Если упоминавшиеся нами исследователи говорили о единичных случаях, то например К.М. Александров заявляет о 20 тысячах русских немцев и так 
называемых «фольксдойче», добровольно вступивших в ряды вермахта [1, с. 122].

Вместе с тем, даже если мы примем цифры Александрова за максимум, то необходимо учитывать, что речь идет, в первую очередь, о российских, а точнее «советских» немцах, населявших западные области страны, в том числе, присоединенные незадолго до войны. Распространение же вывода о массовом коллаборационизме и на немцев Поволжья, на наш взгляд, не имеет под собой достаточных оснований.

Так или иначе, ознакомившись с вышеупомянутым донесением, Сталин поставил под ним ставшую хрестоматийной резолюцию «Надо выселить с треском!» [16, с. 447 - 448]. Представляется, что приведенные донесение и резолюция на нем стали тем окончательным импульсом, который подвиг советское руководство на практическое осуществление депортации немцев.

Длительное время в историографии господствовало убеждение, что единственным документом, положившим начало принудительной депортации немцев Поволжья, является Указ Президиума Верховного Совета СССР от 28 августа 1941 г. «О переселении немцев, проживающих в районах Поволжья». Вместе с тем, советская нормативная система основывалась на решениях партийных органов, которые затем оформлялись в виде законов и указов. Безусловно, что решение государственного масштаба, каковым являлось решение о депортации немцев Поволжья, также первоначально принималось высшим партийным органом, осуществлявшим в то время реальное управление страной, Политбюро ЦК ВКП(б).

В 1991 г. профессор Н.Ф. Бугай в одной из публикаций назвал в качестве документа, положившего начало подготовки и проведения депортации, постановление Совнаркома СССР и ЦК ВКП(б) № 2060сс от 12 августа 1941 г., заметив, что оно пока не найдено [2, с. 173]. Данное утверждение было принято многими позднейшими исследователями. Тем не менее, фронтальное обследование протоколов заседаний Политбюро ЦК ВКП(б) и Особых папок Политбюро за 1941 г., проведенное А.А. Германом, позволило последнему утверждать, что никакого постановления от 12 августа 1941 г. о немцах Поволжья не существовало, и вообще, в этот день, накануне и позднее, вплоть до 26 августа, вопрос о депортации поволжских немцев на заседании Политбюро ЦК ВКП(б) не рассматривался.

Постановление под номером, указанным Н.Ф. Бугаем, существует, но оно вышло 12 сентября 1941 г. и касалось вопросов расселения депортированных российских немцев на территории Казахстана. Первым же документом, фактически явившемся отправной точкой депортации немцев Поволжья, стало Постановление Совнаркома СССР и ЦК ВКП(б) от 26 августа 1941 г. «О переселении немцев из Республики немцев Поволжья, Саратовской и Сталинградской областей в другие края и области» [5, с. 19].

Таким образом, первым документом, решившим судьбу немцев Поволжья, стало постановление Совнаркома СССР и ЦК ВКП(б) от 26 августа 1941 г., разработанное и детализированное в последующих документах. Постановление состояло из 19 пунктов и регламентировало все вопросы переселения. Было расписано, в какой регион сколько человек предполагается направить, сколько для этого потребуется сотрудников силовых структур. Четко прописывались и сроки будущей депортации - с 3 по 20 сентября 1941 г.

При анализе постановления становится очевидно, что планирование 
возможной депортации велось органами НКВД задолго до 26 августа: был проработан план операции, ее технические детали, материальное обеспечение. К моменту выхода указа «О переселении немцев...» уже были подготовлены сведения о численности немецкого населения Саратовской области и Республике немцев Поволжья [9, Л. 53 - 55].

Переселение на новые места надлежало осуществлять как путем «довселения целых колхозов в существующие колхозы и совхозы, так и путем отдельного расселения переселяемого колхоза». Для этого предписывалось использовать все пустующие дома в сельских местностях, при необходимости «уплотнять» живущих там людей. Предлагалось также производить строительство новых домов силами самих переселенцев. Городских жителей можно было поселять в районных центрах и всех городах, за исключением областных.

Переселяемым разрешалось брать с собой личное имущество, мелкий сельскохозяйственный и бытовой инвентарь, продовольствие, всего весом до одной тонны на семью. Принадлежавшие же им постройки, сельхозорудия, скот и зернофураж должны были оставаться на месте и сдаваться по оценочному акту специальным комиссиям. Оставленное недвижимое имущество, продовольствие и скот (кроме лошадей) подлежало «восстановлению» колхозу, колхозникам и единоличникам на новом месте по специальным обменным квитанциям, «за вычетом полного покрытия обязательств по государственным поставкам за 1941 г. и недоимок прошлых лет».

27 августа увидел свет приказ НКВД «О мероприятиях по проведению операции по переселению немцев из Республики немцев Поволжья, Саратовской и Сталинградской областей», регламентирующий проведение готовящейся операции по переселению [10, с. 72 - 73].

Практически одновременно с указом Президиума Верховного Совета СССР от 28 августа 1941 г. «О переселении немцев, проживающих в районах Поволжья» выходит приказ наркома внутренних дел СССР Л. Берии за № 001160, которым был организован отдел спецпоселений НКВД СССР. В последствии данный отдел будет решать все вопросы, связанные с немцами-спецпереселенцами. Начальником ОСП был назначен майор государственной безопасности И.В. Иванов, его заместителем - капитан госбезопасности М.В. Кондратов, который одновременно оставался в должности начальника отдела трудовых и спецпоселений ГУЛАГа НКВД. Приказом предписывалось немедленно выделить ОСП необходимое помещение, телеграфную связь и перевозочные средства.

Обнародован же указ был несколько позднее - 30 августа в республиканских газетах «Нахрихтен» на немецком языке и «Большевик» на русском. Указ заявлял о «десятках тысяч» диверсантов и шпионов, которых скрывали в своей среде немцы Поволжья. Во избежание «карательных мер против всего немецкого населения Поволжья» и предупреждения «серьезных кровопролитий» объявлялось необходимым переселение всех немцев Поволжья в другие районы.

Всего предполагалось переселить 479855 человек, из них в Красноярский край - 75 тыс. в 40 районах, в Алтайский край - 95 тыс. в 58 районах, в Новосибирскую область - 100 тыс. в 45 районах, в Омскую область - 85 тыс. в 57 районах и в Казахскую ССР - 107 тыс. в пяти областях [13, с. 161]. Предполагалось, что переселяемые будут наделены землей и им будет оказана государственная помощь по устройству в новых районах.

Безусловно, что указ был воспринят жителями Сарепты «как гром среди 
ясного неба». Предъявленные тяжкие обвинения воспринимались с недоумением. Конечно, у людей, переживших репрессии 1930-х гг. складывалось вполне определенное, отнюдь не радужное представление о своей дальнейшей судьбе. Усугублялось положение тем, что данный указ должен был сформировать негативный образ поволжских немцев у представителей других национальностей, живших ранее бок о бок с ними. В докладной записке первого секретаря обкома ВКП(б) АССР НП С. Малова на имя Сталина говорилось: «подавляющее большинство трудящихся русской и других (кроме немецкой) национальностей встретили Указ с большим одобрением, рассматривая его как одну из серьезных мер по укреплению тыла...» [6, Л. 5]. При этом в качестве подтверждения приводятся высказывания откровенно оскорбительного плана. Так, не названный, «один рабочий» в неназванной ситуации заявил: «Да, вот теперь они (т. е. немцы. - В.Ш.) запоют не так. Пусть и туда поедут так же дружно, как они старались втирать свою немчуру вокруг! Теперь я спокойно могу пойти на фронт, зная, что моя семья будет вне опасности от внутреннего врага».

Вместе с тем, большинство жителей Поволжья сохраняли к согражданам немецкой национальности прежнее человеческое отношение, восприняв близко к сердцу трагедию депортации. Например, А. Герман упоминает о «спецсообщении» № 124cс от 13 сентября 1941 г. «О выражении сожаления и организации подарков для переселяемых немцев в столовой-ресторане № 7, в облпотребсоюзе, в дорпрофсоже РУЖД и 43 средней школе» [5, с. 37].

Вместе с тем, неоднозначная моральная обстановка не стала благоприятной почвой для пораженческих и антисоветских настроений среди депортируемых. Однозначным подтверждением данного тезиса служит та организованность, с которой жителями Красноармейска немецкой национальности был исполнен указ о депортации: большинство из них работало на своих местах до последнего дня; отмечается отсутствие недовольных, т.к. все воспринимали вывоз как эвакуацию от наступающих войск Германии. Подобной точки зрения придерживалось и руководство Республики немцев Поволжья, местный актив и лица, проводившие акцию. Немцы выражали сожаление по поводу оставленных домов, мебели и прочих вещей, которые нельзя было взять с собой, ибо администрация полностью выполняла и поддерживала инструкцию по переселению.

Отметим, что массовых случаев насилия со стороны сотрудников органов, проводивших депортацию, по отношению к немцам Поволжья, так же не отмечается. Уже с 29 августа оперативные группы из числа работников НКВД начали заполнять учетные карточки на каждую семью, подлежащую переселению из Красноармейска. Характерно, что проводить перепись должны были сами депортируемые. Помимо полного состава семьи на карточках указывался номер эшелона и регион, куда предстояло переселиться [3, с. 41].

Выселение из Красноармейска было проведено в основном 1 и 2 сентября 1941 г. Всего было депортировано 643 семьи общим числом 2320 человек. В сводке № 2 о ходе операции по переселению немцев Поволжья отмечалось, что всего из Сталинградской области было депортировано 24232 человека. Отказов от переселения при этом зафиксировано не было.

Сотрудники НКВД, проводившие выселение, сажали депортируемых на подводы и отправляли к Красноармейскому затону, где их уже ждали баржи и сопровождающий катер. Дома запирались на ключ и опечатывались. Покорившись судьбе, депортируемые шли парами на баржи, исполняя при этом по-немецки 
псалмы. После погрузки баржи были отправлены в Астрахань, оттуда по Каспийскому морю переселенцы направлялись до Гурьева и лишь затем железнодорожным транспортом к местам расселения.

А.А. Герман отмечает, что у большинства депортированных море вызывало страх. Начали распространяться панические слухи о том, что немцев вывозят в море для того, чтобы утопить. В связи с этим 7 сентября на барже № 063, стоявшей на астраханском причале в ожидании отправки, поднялась паника. Применив суровые меры, охрана навела порядок.

Организацию массовой перевозки депортируемых по железной дороге регламентировала «Инструкция начальникам эшелонов по сопровождению немцев-переселенцев». Она предписывала начальникам эшелонов обеспечивать переселенцев в необходимом объеме питанием и медицинской помощью. Подчеркивалось, что необходимо сохранить контингент в полном составе. Переселенцы дважды в сутки должны были получать кипяток и горячее бесплатное питание, а также по 500 г хлеба на человека. Горячая пища и хлеб выдавались в железнодорожных буфетах, для чего выделялись соответствующие денежные средства и продукты питания [8, Л. 12].

Несмотря на строгую регламентацию, обстановка начала войны вносила свои корректировки в перевозки переселенцев к новому месту жительства. Так, нехватка подвижного состава, требовавшегося, в первую очередь, для воинских перевозок, приводила к тому, что зачастую в вагоны вместо положенных 40 человек загружали до 60 [7, Л. 45]. Естественно, что график движения эшелонов, следовавших на восток, зачастую не соблюдался. Иногда на станциях поселенцам приходилось проводить по несколько дней. При этом не все вагоны были оборудованы нарами, печками для отопления и изоляторами для больных. Организация питания в пути следования также оставляла желать лучшего: питание чаще всего было одноразовым и нерегулярным, состояло только из одного блюда. Очереди в буфетах и неразбериха со временем отправки поездов приводили к большому количеству отставших от поезда, достигавшего по некоторым эшелонам до нескольких сотен человек.

Впрочем, нельзя утверждать, что подобная ситуация в дороге была вызвана исключительно отрицательным отношением к российским немцам со стороны Советского государства. В аналогичных условиях зачастую оказывались и граждане других национальностей, эвакуируемые от линии фронта. Отметим, что эшелоны с депортируемыми и эвакуированными днями стояли на одних путях, охрана не выставлялась, а питались они в одних и тех же буфетах, стоя в одних и тех же очередях.

В целом можно утверждать, что, несмотря на все трудности, перевозка депортированных была осуществлена без серьезных отклонений от установленных сроков, без каких-либо серьезных эксцессов. Сказывалась дисциплинированность немцев и предопределенная религиозным мировоззрением покорность судьбе.

Всего в 188 эшелонах по состоянию на конец октября 1941 г. было перевезено 438280 поволжских немцев [7, Л. 45]. При этом, несмотря на непростые санитарные условия, массовой смертности в пути удалось избежать. В среднем по эшелону расхождение списочного состава не превышает 70 человек. Причем, в это число входят не только умершие, но и отставшие, которых, как говорилось ранее, было не мало. Нельзя при этом не учитывать и погрешность в 
счете при загрузке и выгрузке, поскольку, как отмечается в сводках о ходе переселения, в ряде случаев повагонные списки депортируемых фактически отсутствовали [8, Л. 89].

Около 73\% немецкого населения Поволжья было переселено в Сибирь и лишь $27 \%$ - в Казахстан. В Красноярский край и Павлодарскую область последние эшелоны пришли в первых числах октября, в Алтайский край и другие области - раньше, еще до начала октября. Переселенцы из Поволжья начали жизнь в новых, незнакомых большинству из них условиях.

В Сибири местные органы власти и простые колхозники, которым предстояло принимать у себя немцев, проделали большую работу по подготовке жилья. Поэтому значительная часть депортированных смогла расселиться в достаточно приемлемых условиях, в помещениях, в которых был проведен ремонт $[3$, c. 62].

Переселенцы, попавшие из Поволжья в Казахстан, были размещены в северной, восточной и юго-восточной частях республики, т.е. в районах, сравнительно благоприятных для жизни. Здесь они столкнулись с принципиально другой культурой, религией, обычаями. Зачастую, на первых порах незнание местных традиций приводило к бытовым конфликтам.

В целом же на новом месте немцев изначально воспринимали как эвакуированных. Позднее же органы на местах получили директиву «немцевпереселенцев к эвакуированному населению не причислять» [18, с. 120].

Многим депортированным из Красноармейска немцам пришлось непросто на новом месте. Часть их попала в восточный Казахстан, часть в Сибирь, другие в Туркмению, на Урал. Дальше их ждали трудные годы в ссылке, работа в трудовых армиях (трудармиях). Это были особые подразделения из депортированных, где они занимались тяжелым принудительным трудом.

Были и другие трудности: предполагалось, что на местах поселения депортированные немцы получат скот и иное имущество в соответствии с оценочно-стоимостными актами, составляемыми перед депортацией, однако большинстве случаев данные положения на практике не выполнялись. Впрочем, здесь тоже не было особого умысла со стороны властей: зачастую для этого просто не было средств, поскольку в условиях войны вдруг найти свободные материальные ресурсы местное руководство могло с трудом.

Таким образом, можно констатировать, что депортация немцев Поволжья была уникальной операцией. С точки зрения мирного времени она носит, безусловно, принудительный и противоправный характер. Вместе с тем, жесткая логика времени военного, которой руководствовалось советское руководство, позволяет говорить если не о необходимости, то по крайней мере об определенной потребности в данном шаге для интересов обороноспособности страны. Не будем забывать о ключевой роли Поволжья в тот период и о последствиях, которые теоретически могли наступить в случае действий «пятой колонны». Примечательно, что данная операция была фактически оправдана со стороны мирового сообщества, признавшего ее необходимой процедурой, сопоставимой с процессами, происходившими во многих странах.

Понимая огульность обвинений, советское руководство всеми средствами старалось минимизировать негативные последствия как для страны, так и для самих переселенцев. Об этом говорят четкость разработки операции, отсутствие высокой смертности и отлаженность механизма оперативного управления НКВД, 
a также отсутствие произвола со стороны властей по отношению к депортируемым. Однако полностью их избежать было невозможно. Фактически, позитивный эффект от данного мероприятия для обороноспособности был сведен на «нет» негативным влиянием на социальные, правовые, культурные и экономические аспекты жизни депортированных народов в будущем. 


\section{Литература}

1. Александров К.М. Против Сталина. Власовцы и восточные добровольцы во Второй мировой войне. - Санкт-Петербург, 2003.

2. Бугай Н.Ф. 40-е годы: «автономию немцев Поволжья ликвидировать...» // История СССР. - 1991. - № 2.

3. Вашкау Н.Э. Сарепта. Страницы истории российских немцев. - Волгоград, 2006.

4. Герман А.А. Большевизм и немецкая автономия на Волге. - Саратов, 2004.

5. Герман А.А. Депортация немцев Поволжья // «Выселить с треском». Очевидцы и исследователи о трагедии российских немцев: Сб. научн. статей и воспоминаний. - М., 2011.

6. Государственный архив новейшей истории Саратовской области. Ф. 1. Оп. 1. Д. 5031.

7. Государственный архив Российской Федерации (далее - ГАРФ). Ф. 9479. Оп. 1. Д. 83.

8. ГАРФ. Ф. 9479. Оп. 1. Д. 84

9. ГАРФ. Ф. 9479. Оп. 1. Д. 85.

10. Депортация народов СССР. Ч. 2. Депортация немцев (сентябрь 1941 февраль 1942 г.). - М., 1995.

11. Егорова М.В. Поволжские немцы в стремлении к сохранению национальной идентичности, традиционных устоев жизни (1918-1941 гг.). Дис... канд. ист. наук. - Саратов, 2006.

12. Ионг де Л. Немецкая пятая колонна во Второй мировой войне. - М., 1958.

13. История российских немцев в документах (1763 - 1992). Сост. к.и.н. В.А. Ауман, д.и.н. В.Г. Чеботарева. - М., 1993.

14. Лубянка. Сталин и Главное управление госбезопасности НКВД. Архив Сталина. Документы высших органов партийной и государственной власти. 1937 - 1938. - М., 2004.

15. Мартыненко В.Л. Депортация немцев с территории Украины // «Выселить с треском». Очевидцы и исследователи о трагедии российских немцев: Сб. научн. статей и воспоминаний / Под ред. А.А. Германа, О.Ю. Силантьевой. - М., 2011.

16. Органы государственной безопасности в Великой Отечественной войне: Сборник документов. Т. 1. Кн. 2. Начало. 22 июня -31 августа 1941 г. - М., 2000. 
17. Охотин Н., Рогинский А. Из истории «немецкой операции» НКВД 1937 1938 гг. // Репрессии против российских немцев. Наказанный народ. - М., 1999.

18. Чебыкина Т. Депортация немецкого населения из европейской части СССР в Западную Сибирь (1941 - 1945) // Репрессии против российских немцев. Наказанный народ. - М., 1999. 